\title{
Pengaruh Disiplin Kerja Terhadap Kinerja Karyawan Pada PT. Agro Massiv International Group
}

\author{
Adie Kurbani \\ Fakultas Ekonomi Universitas PGRI Palembang, \\ email: adie78kurbani@univpgri-palembang
}

\begin{abstract}
ABSTRAK
Penelitian ini bertujuan untuk menguji dan mengetahui ada tidaknya Pengaruh Disiplin Kerja Terhadap Kinerja Karyawan Pada PT. Agro Massiv International Group. Populasi dalam penelitian ini adalah seluruh karyawan PT. Agro Massiv International Group sebanyak 233 orang karyawan. Sampel ditentukan dengan teknik simple random sampling, dengan responden sebanyak 69 orang karyawan. Metode pengumpulan data yang digunakan adalah data primer dan data sekunder. Analisis data yang digunakan adalah analisis regresi linier sederhana,koefisien korelasi,uji t (secara parsial). Hasil pembahasan diperoleh nilai uji $t$ untuk variabel disiplin kerja diperoleh $t$ hitung 4,231 dengan nilai signifikansi sebesar $0,000<0,05$ karena nilai probabilitas signifikan kurang dari 0,05 , maka dapat disimpulkan bahwa secara parsial $\mathrm{H}_{\circ}$ ada pengaruh disiplin kerja terhadap kinerja karyawan. Hasil koefisien korelasi sebesar 0,459 atau $45,9 \%$ dan sisanya $54,1 \%$ dijelaskan oleh variabel-variabel lain yang tidak dijelaskan dalam penelitian ini.
\end{abstract}

Kata Kunci: Disiplin kerja dan kinerja karyawan.

\section{A. Latar Belakang}

Keberhasilan setiap perusahaan tidak hanya tergantung dengan teknologi perusahaan melainkan juga pada aspek sumber daya manusia yang dimiliki oleh perusahaan. Suatu perusahaan membutuhkan sumber daya manusia yang potensial, baik pemimpin maupun karyawan dapat memberikan kontribusi yang baik dan melaksanakan tugas dengan optimal untuk mencapai tujuan perusahaan. Sumber daya manusia memiliki posisi sangat strategis dalam organisasi, artinya unsur manusia memiliki peranan penting dalam melakukan aktivitas untuk mencapai tujuan. Untuk itulah eksistensi sumber daya manusia sangat kuat. Manusia berperan aktif dan dominan dalam setiap kegiatan organisasi karena manusia menjadi perencana, pelaku dan penentu terwujudnya tujuan organisasi .

Persaingan dunia usaha saat ini semakin kompetitif, karena itu setiap perusahaan harus mampu mengatur dan mengolah semua sumber daya yang dimilikinya dengan efektif dan efisien agar tetap dapat bertahan hidup dan berkembang. Salah satu sumber daya perusahaanadalah tenaga kerja atau karyawan. Setiap perusahaan pasti mengharapkan tenaga kerja atau karyawannya memberikan hasil yang maksimal di dalam bekerja.

Kinerja karyawan diharapkan berjalan dengan efektif, hal tersebut tidak hanya didorong dengan adanya sumber daya manusia saja tetapi dengan disiplin kerja yang tinggi. Hasibuan(2009:193) mendefinisikan disiplin kerja sebagai kesadaran dan kesediaan seseorang menaati peraturan perusahaan dan normanorma sosial yang berlaku. Kesadaran adalah sikap seseorang yang secara sukarela mentaati semua peraturan dan sadar akan sikap dan tanggung jawabnya. Kesediaan adalah suatu sikap, tingkah laku, dan perbuatan seseorang yang sesuai peraturan perusahaan, baik yang tertulis maupun 
tidak. Sedangkan Mangkunegara (2014:67) menjelaskan kinerja karyawan adalah hasil kerja kualitas dan kuantitas yang dicapai oleh seorang karyawan dalam melaksanakan tugasnya sesuai dengan tanggung jawab yang diberikan kepadanya.

Disiplin merupakan tindakan manajemen untuk mendorong para anggota organisasi memenuhi tuntutan berbagai ketentuan yang harus ditaati oleh karyawan. Pendisiplinan karyawan adalah memperbaiki dan membentuk pengetahuan, sikap dan perilaku karyawan sehingga karyawan dapat bekerja secara kooperatif dengan karyawan yang lain serta meningkatkan prestasi kerjanya

Disiplin kerja diantaranya disiplin waktu kerja dan disiplin dalam mentaati peraturan yang telah diterapkan oleh perusahaan. Dengan adanya kesadaran yang tinggi dalam melaksanakan aturan-aturan perusahaan yang diwujudkan dalam disiplin kerja yang tinggi, maka disiplin kerja akan tercapai. Perusahaan tidak perlu bersikap lemah dalam dalam menghadapi para karyawan yang ada di perusahaan. Seorang pimpinan yang lemah bukan hanya akan mengacaukan jalannya perusahaan tetapi juga akan kehilangan rasa hormat dari para bawahannya.

Tingginya disiplin kerja karyawan akan mampu mencapai prestasi kerja yang maksimal, baik itu disiplin waktu, tata tertib atau peraturan yang telah ditetapkan dalam perusahaan tersebut. Untuk lebih mengefektifkan peraturan yang telah dikeluarkan dalam rangka menegakkan kedisiplinan perlu teladan dari pimpinan. Teladan pimpinan sangat berperan dalam menentukan kedisiplinan karyawan karena pimpinan dijadikan sebagai panutan oleh para karyawannya.
Selain disiplin kerja ada hal yang lain juga penting untuk meningkatkan prestasi kerja karyawan yaitu adanya pengawasan dari pimpinan yang perlu memperhatikan segala kegiatan dan yang paling penting adalah kebutuhannya akan selalu dihargai. Jika mereka dalam melaksanakan aktivitas pekerjaannya dengan baik dan menghasilkan hasil kerja yang baik maka akan tercapai prestasi kerja yang maksimal sedangkan tujuan pengawasan itu merupakan hasil pelaksanaan pekerjaan diperoleh secara berdaya guna dan berhasil guna sesuai dengan rencana yang telah ditentukan, sehingga dengan pengawasan karyawan merasa terdorong untuk bekerja lebih baik kemudian menghasilkan pekerjaan yang memuaskan bagi perusahaan atau organisasinya. Disiplin sangat berhubungan dengan kinerja karyawan, faktor disiplin sangat diharapkan dalam rangka meningkatkan kinerja karyawan, supaya pencapaian yang diharapkan dapat terwujud dikemudian hari.

Karyawan merupakan salah satu faktor produksi yang terpenting dalam suatu perusahaan, tanpa mereka betapa sulitnya perusahaan dalam mencapai tujuan. Untuk itu setiap perusahaan atau organisasi selalu berusaha agar dapat meningkatkan kualitas sumber dayanya. Sudah menjadi kewajiban bagi karyawannya untuk dapat memberikan kemampuan kerjanya dengan baik sesuai dengan pembagian tugasnya masing-masing. Karyawan yang baik dapat dilihat dari disiplin kerjanya.

PT. Agro Massiv International Group merupakan perusahaan yang bekerja dibidang perkebunan kelapa sawit manajemen harus memahami artinya disiplin kerja agar pencapaian kinerja karyawan efektif. Upaya penegakan disiplin kerja tidak berjalan 
mulus begitu saja karena adanya pelanggaran peraturan disiplin berupa tidak mentaati peraturan seperti : keluar kantor pada jam kerja yang bukan kepentingan kerja atau pulang dari lapangan pada jam kerja, bahkan hanya mengabsen padahal tidak hadir dilapangan, bermain game dikomputer, dan tidak mentaati jam kerja yang ditentukan.

Berdasarkan fenomena yang terjadi pada PT. Agro Massiv International Group sebaiknya karyawan mampu bekerja sama untuk mewujudkan kedisiplinan dalam melakukan setiap pekerjaan sehingga dapat meningkatkan kinerja bagi organisasi, bila ada seorang karyawan yang melanggar disiplin, maka perlu ada keberanian pimpinan untuk mengambil tindakan yang sesuai dengan tingkat pelanggaran yang dibuatnya.

\section{B. Rumusan Masalah}

Berdasarkan latar belakang diatas, maka masalah yang dirumuskan adalah sebagai berikut : "Bagaimana pengaruh disiplin kerja terhadap kinerja karyawan pada PT. Agro Massiv International Group ?".

\section{Metode Penelitian}

Sugiyono (2015:2) mendefiniskan metode penelitian adalah cara ilmiah untuk mendapatkan data dengan tujuan dan kegunaan tertentu. Metode penelitian data yang digunakan dalam penelitian ini adalah metode kuantitatif

Sugiyono (2015:8) mendefinisikan metode kuantitatif yaitu metode penelitian yang digunakan untuk meneliti pada populasi atau sampel tertentu, teknik pengambilan sampel pada umumnya dilakukan secara random, pengumpulan data menggunakan instrumen penelitian, analisis data bersifat kuantitatif/statistik dengan tujuan untuk menguji hipotesis yang telah ditetapkan.

\section{Populasi dan Sampel}

1) Populasi

Sugiyono

$(2015: 80)$

mendefinisikan populasi sebagai wilayah generalisasi yang terdiri atas: obyek/subyek yang mempunyai kualitas dan karakteristik tertentu yang ditetapkan oleh peneliti untuk dipelajari dan kemudian ditarik kesimpulannya. Populasi dalam penelitian ini adalah seluruh karyawan yang ada di PT. Agro Massiv International Group sebanyak 233 karyawan berdasarkan data yang ada pada absensi perusahaan tersebut.

\section{2) Sampel}

$$
\text { Sugiyono }
$$

mendefinisikan sampel adalah bagian dari jumlah dan karakteristik yang dimiliki oleh populasi tersebut. Bila populasi besar, dan peneliti tidak mungkin mempelajari semua yang ada pada populasi, misalnya karena keterbatasan dana, tenaga, dan waktu, maka peneliti dapat menggunakan sampel yang di ambil dari populasi itu. Apa yang dipelajari dari populasi itu, kesimpulannya dapat di berlakukan untuk populasi.

Sugiyono

mendefinisikan sampel sebagai sebagian atau wakil populasi yang diteliti. Teknik pengambilan sampel dengan sampel non probilitas yaitu menggunakan metode rand sampling. Random sampling adalah mengambil sampel secara acak. Jumlah sampel yang ditetapkan oleh peneliti, mengacu kepada rumus Slovin sebagai berikut:

$$
\begin{aligned}
& \begin{array}{l}
n=\frac{N}{1+\left(N \cdot e^{2}\right)}=\frac{233}{1+\left(233.0,1^{2}\right)}=\frac{233}{3.33} \\
\quad=69,97 \text { responden }
\end{array} \\
& \text { Keterangan : } \\
& \mathrm{n} \quad: \text { Ukuran sampel } \\
& \mathrm{N} \quad: \text { Ukuran populasi } \\
& \mathrm{e} \quad: \text { Presisi yang ditetapkan } 10 \%
\end{aligned}
$$


E. Teknik Pengumpulan Data

Sugiyono (2013:137-142)

mengemukakan teknik pengumpulan data terdiri dari:

1) Observasi, adalah suatu proses yang kompleks, suatu proses yang tersusun dari berbagai proses biologis dan fisikologis. Dua diantara yang terpenting adalah prosesproses pengamatan dan ingatan.

2) Wawancara, adalah teknik pengumpulan data apabila peneliti ingin melakukan studi pendahuluan untuk menemukan permasalahan yang harus diteliti, dan juga apabila peneliti ingin mengetahui hal-hal dari kecil responden yang lebih mendalam dan jumlah respondennya sedikit/kecil.

3) Kuesioner merupakan teknik pengumpulan data yang dilakukan dengan cara memberi seperangkat pertanyaan atau pernyataan tertulis kepada responden untuk dijawabnya.

\section{F. Teknik Analisis Data}

1) Regresi Linear Sederhana
Riduan

mengemukakan regresi linier sederhana adalah salah satu alat yang dapat digunakan dalam memprediksi permintaan dimasa akan datang berdasarkan data masa lalu atau untuk mengetahui pengaruh satu variabel bebas (independent) terhadap satu variabel tak bebas (dependent).

Rumus regresi linier sederhana

\section{$Y=a+b \cdot X$}

Dimana :

$X=$ Variabel bebas

$\mathrm{Y}=$ Variabel terikat

a=Bilangan konstanta

$b=$ koefisien arah regresi

\section{2) Koefisien Kolerasi}

Sugiyono

menjelaskan koefisien kolerasi merupakan alat untuk mengetahui kuat tidaknya hubungan antara variabel bebas dan terikat . adapun nilai koefisien kolerasi dapat dicari dengan rumus:

Dimana $: r_{\mathrm{xy}}=\frac{n \sum X Y-\left(\sum X\right)\left(\sum Y\right)}{\sqrt{\left\{\left(n \sum X^{2}-\left(\sum X^{2}-\left(\sum X\right)^{2}\right\}\left\{n \sum Y^{2}-\left(\sum Y\right)^{2}\right\}\right.\right.}}$

$r_{x y} \quad$ : korelasi antar variabel $x$ dan $y$

$r \quad:$ koefisien korelasi

$\mathrm{X} \quad$ : variabel bebas, $\mathrm{Y}$ : variabel terikat

$\mathrm{n} \quad$ : jumlah data

bahwa untuk mengetahui tingkat hubungan antar variabel di jelaskan oleh koefisien korelasi sebagai berikut

Tabel 1

\begin{tabular}{|c|c|}
\hline Interval koefisien & Tingkat hubungan \\
\hline $0,00-0,199$ & Sangat rendah \\
$0,20-0,399$ & Rendah \\
$0,40-0,599$ & Sedang \\
$0,60-1,799$ & Kuat \\
$0,80-1,000$ & Sangat kuat \\
\hline
\end{tabular}

Teknik analisis data yang penulis gunakan yakni teknik analisis data deskriptif kuantitatif, yaitu suatu motode analisis yang menggunakan perhitungan angka-angka untuk mengambil keputusan dan penjelasan.

\section{G. Hasil Penelitian}

1) Hasil Uji Validitas Disiplin Kerja (X)

Uji signifikansi dilakukan dengan membandingkan nilai $r$ hitung dengan nilai $r$ tabel. Jika $r$ hitung $>r$ tabel dan berkorelasi positif, maka butir atau pertanyaan tersebut valid. Atau dengan kata lain item pertanyaan dikatakan valid apabila skor item pertanyaan 
memiliki korelasi yang positif dan Uji validitas disiplin kerja yaitu : signifikan dengan skor total variabel.

Tabel 2

Hasil Uji Validitas Disiplin Kerja

\begin{tabular}{|c|c|c|c|c|c|}
\hline No & Item Pertanyaan & $r_{\text {table }}$ & $r_{\text {hitung }}$ & Kriteria & Keterangan \\
\hline 1 & Item 1 & 0,444 & 0,444 & $r$ hitung $>r$ table & Valid \\
\hline 2 & Item 2 & 0,444 & 0,566 & $r$ hitung $>r$ table & Valid \\
\hline 3 & Item 3 & 0,444 & 0,648 & $r$ hitung $>r$ table & Valid \\
\hline 4 & Item 4 & 0,444 & 0,599 & $r$ hitung $>r$ table & Valid \\
\hline 5 & Item 5 & 0,444 & 0,563 & $r$ hitung $>r$ table & Valid \\
\hline 6 & Item 6 & 0,444 & 0,538 & $r$ hitung $>r$ table & Valid \\
\hline 7 & Item 7 & 0,444 & 0,586 & $r$ hitung $>r$ table & Valid \\
\hline 8 & Item 8 & 0,444 & 0,486 & $r$ hitung $>r$ table & Valid \\
\hline 9 & Item 9 & 0,444 & 0,493 & $r$ hitung $>r$ table & Valid \\
\hline 10 & Item 10 & 0,444 & 0,475 & $r$ hitung $>r$ table & Valid \\
\hline 11 & Item 11 & 0,444 & 0,475 & $r$ hitung $>r$ table & Valid \\
\hline 12 & Item 12 & 0,444 & 0,493 & $r$ hitung $>r$ table & Valid \\
\hline 13 & Item 13 & 0,444 & 0,475 & $r$ hitung $>r$ table & Valid \\
\hline 14 & Item 14 & 0,444 & 0,626 & $r$ hitung $>r$ table & Valid \\
\hline 15 & Item 15 & 0,444 & 0,587 & $r$ hitung $>r$ table & Valid \\
\hline 16 & Item 16 & 0,444 & 0,491 & $r$ hitung $>r$ table & Valid \\
\hline
\end{tabular}

Sumber: Data primer 2016

Nilai dari pertanyaan nomor 1 $\mathrm{s} / \mathrm{d} 16$ adalah $r$ hitung $>r$ tabel $=0,444>$ 0,444 maka $\mathrm{H}_{0}$ ditolak $\mathrm{H}_{\mathrm{a}}$ diterima menunjukkan bahwa hasil uji validitas dari 16 item pertanyaan pada variabel disiplin kerja keseluruhan valid. Dengan demikian keseluruhan item pertanyaan yang ada pada instrumen tersebut dapat dijadikan sebagai alat ukur yang valid dalam analisis selanjutnya.

\section{2) Hasil Uji Validitas Kinerja Karyawan (Y)}

Uji signifikansi dilakukan dengan membandingkan nilai $r$ hitung dengan nilai $r$ tabel. Jika $r$ hitung $>r$ tabel dan berkorelasi positif, maka butir atau pertanyaan tersebut valid. Atau dengan kata lain item pertanyaan dikatakan valid apabila skor item pertanyaan memiliki korelasi yang positif dan signifikan dengan skor total variabel. Uji validitas kinerja karyawan yaitu :

Tabel 3

Hasil Uji Validitas Kinerja Karyawan (Y)

$\begin{array}{cc}\text { No } & \text { Item Pertanyaar } \\ 1 & \text { Item 1 } \\ 2 & \text { Item 2 } \\ 3 & \text { Item 3 } \\ 4 & \text { Item 4 } \\ 5 & \text { Item 5 } \\ 6 & \text { Item 6 } \\ 7 & \text { Item 7 } \\ 8 & \text { Item 8 } \\ 9 & \text { Item 9 } \\ 10 & \text { Item 10 } \\ 11 & \text { Item 11 } \\ 12 & \text { Item 12 } \\ 13 & \text { Item 13 } \\ 14 & \text { Item 14 } \\ \text { Sumber : Diolah 2016 }\end{array}$

$r_{\text {table }}$

0,444

0,444

0,444

0,444

0,444

0,444

0,444

0,444

0,444

0,444

0,444

0,444

0,444

0,444 $\boldsymbol{r}$ hitung

0,614

0,854

0,632

0,894

0,614

0,553

0,765

0,921

0,606

0,861

0,753

0,832

0,785

0,850

\section{Kriteria}

$r_{\text {hitung }}>r_{\text {table }}$

$r_{\text {hitung }}>r_{\text {table }}$

$r_{\text {hitung }}>r_{\text {table }}$

$r$ hitung $>r$ table

$r$ hitung $>r$ table

$r$ hitung $>r$ table

$r$ hitung $>r_{\text {table }}$

$r$ hitung $>r$ table

$r$ hitung $>r$ table

$r$ hitung $>r$ table

$r$ hitung $>r_{\text {table }}$

$r_{\text {hitung }}>r_{\text {table }}$

$r$ hitung $>r$ table

$r$ hitung $>r_{\text {table }}$
Keterangan

Valid

Valid

Valid

Valid

Valid

Valid

Valid

Valid

Valid

Valid

Valid

Valid

Valid

Valid 
Nilai dari pertanyaan nomor. $1 \mathrm{~s} / \mathrm{d}$ 14 " $r$ hitung $>r$ tabel" $=0,614>0,444$ maka $\mathrm{H}_{0}$ ditolak $\mathrm{H}_{\mathrm{a}}$ diterima menunjukkan bahwa hasil uji validitas dari 14 item pertanyaan pada variabel kinerja karyawan keseluruhan valid. Dengan demikian keseluruhan item pertanyaan yang ada pada instrumen tersebut dapat dijadikan sebagai alat ukur yang valid dalam analisis selanjutnya.

\section{3) Hasil Uji Reliabilitas}

\section{Ghozali (dalam Sujarweni} 2014:169) menjelaskan uji reliabilitas dilakukan terhadap item pertanyaan yang dinyatakan valid. Uji ini digunakan untuk mengukur suatu kuesioner yang merupakan indikator dari variabel atau konstruk. Suatu kuesioner dikatakan reliabel atau handal jika jawaban seseorang terhadap pernyataan adalah konsisten atau stabil dari waktu ke waktu. Suatu variabel dikatakan reliabel jika memiliki Cronbach Alpha> 0,60 .

\section{a) Reliabilitas Disiplin Kerja (X)} Hasil uji reliabilitas variabel disiplin kerja yaitu dengan hasil sebagai berikut

Tabel 4

Reliabilitas Disiplin Kerja Reliability Statistics

\begin{tabular}{|l|l|}
\hline $\begin{array}{l}\text { Cronbach's } \\
\text { Alpha }\end{array}$ & N of Items \\
\hline, 906 & 16 \\
\hline
\end{tabular}

Sumber : Data Primer 2016
Hasil uji reliabilitas didapat nilai Cronbach' Alpha sebesar 0,906 karena nilai diatas 0,60 maka dapat disimpulkan bahwa alat ukur dalam penelitian ini reliabel dan dapat dijadikan alat ukur dianalisis selanjutnya.

\section{b) Reliabilitas Kinerja Karyawan} (Y)

Hasil uji reliabilitas variabel Kinerja Karyawan yaitu dengan hasil sebagai berikut :

\section{Tabel 5}

Reliabilitas Kinerja Karyawan Reliability Statistics

\begin{tabular}{|l|l|}
\hline $\begin{array}{l}\text { Cronbach's } \\
\text { Alpha }\end{array}$ & N of Items \\
\hline, 970 & 14 \\
\hline \multicolumn{2}{|l|}{ Sumber : Data Diolah, 2016 }
\end{tabular}

Hasil uji reliabilitas didapat nilai Cronbach Alpha sebesar 0,970 karena nilai diatas 0,60 maka dapat disimpulkan bahwa alat ukur dalam penelitian ini reliabel dan dapat dijadikan alat ukur dianalisis selanjutnya.

\section{c) Uji Normalitas}

Menurut Priyatno (2014:163) uji normalitas residual digunakan untuk menguji apakah nilai residual yang dihasilkan dari regresi terdistribusi secara normal atau tidak. Model regresi yang baik adalah yang memiliki nilai residual yang terdistribusi secara normal. 
Tabel 6

Hasil Uji normalitas

One-Sample Kolmogorov-Smirnov Test

\begin{tabular}{|c|c|c|}
\hline & & $\begin{array}{l}\text { Unstandardized } \\
\text { Residual }\end{array}$ \\
\hline $\begin{array}{l}\text { N } \\
\text { Normal Parameters }{ }^{a, b} \\
\text { Most Extreme Differences } \\
\text { Test Statistic } \\
\text { Asymp. Sig. (2-tailed) }\end{array}$ & $\begin{array}{l}\text { Mean } \\
\text { Std. Deviation } \\
\text { Absolute } \\
\text { Positive } \\
\text { Negative }\end{array}$ & $\begin{array}{l}69 \\
.0000000 \\
3.14630712 \\
.095 \\
.095 \\
-.071 \\
.095 \\
.199 c\end{array}$ \\
\hline
\end{tabular}

a. Test distribution is Normal.

b. Calculated from data.

c. Lilliefors Significance Correction.

Sumber : Data diolah 2016

Dari output diatas dapat diketahui bahwa nilai signifikansi (Asymp.Sig 2tailed) sebesar 0,199. Karena nilai signifikansi lebih dari 0,05 , maka nilai residual terdistribusi dengan normal. d) Regresi Linear Sederhana

Regresi linier sederhana digunakan untuk mengetahui pengaruh variabel disiplin kerja terhadap kinerja karyawan.

Tabel 7

Coefficients $^{a}$

\begin{tabular}{|c|c|c|c|c|c|c|}
\hline \multirow{2}{*}{\multicolumn{2}{|c|}{ Model }} & \multicolumn{2}{|c|}{$\begin{array}{l}\text { Unstandardized } \\
\text { Coefficients }\end{array}$} & \multirow{2}{*}{\begin{tabular}{|l}
$\begin{array}{l}\text { Standardized } \\
\text { Coefficients }\end{array}$ \\
Beta \\
\end{tabular}} & \multirow[b]{2}{*}{$\mathrm{T}$} & \multirow[b]{2}{*}{ Sig. } \\
\hline & & B & Std. Error & & & \\
\hline & $\begin{array}{l}\text { (Constant) } \\
\text { Disiplin } \\
\text { Keria }\end{array}$ & $\begin{array}{l}33,046 \\
, 307\end{array}$ & $\begin{array}{l}4,964 \\
, 073\end{array}$ & 459 & $\begin{array}{l}6,657 \\
4,231\end{array}$ & $\begin{array}{l}., 000 \\
, 000\end{array}$ \\
\hline
\end{tabular}

a. Dependent Variable: Kinerja Karyawan

Diperoleh persamaan regresi :

$\mathrm{Y}=\mathrm{a}+\mathrm{bX}$

$Y=33,046+0,307 X$

Tabel 7 menunjukkan nilai konstan sebesar 33,046 artinya jika disiplin kerja nilainya 0 , maka kinerja karyawan nilainya 33,046 , sedangkan korelasi regresi variabel sebesar 0,307 artinya displin kerja sebesar 1 satuan maka kinerja karyawan akan mengalami peningkatan sebesar 0,307 dan sebaliknya apabilah kinerja karyawan menurun sebesar 1 satuan maka disiplin kerja akan mengalami penurunan sebesar 33,046 .

\section{e) Koefisien Korelasi}

Koefisien kolerasi digunakan untuk mengetahui kuat tidaknya hubungan antara variabel disiplin kerja terhadap kinerja. 
Model Summary ${ }^{b}$

Tabel 8

\begin{tabular}{|l|l|l|ll|l|}
\hline Model & $\mathbf{R}$ & $\begin{array}{l}\mathrm{R} \\
\text { Square }\end{array}$ & $\begin{array}{l}\text { Adjusted } \\
\text { Square }\end{array}$ & $\begin{array}{l}\text { Std. Error of the } \\
\text { Estimate }\end{array}$ \\
\hline $\mathbf{1}$ &, $\mathbf{4 5 9 ^ { \mathbf { a } }}$ &, 211 &, 199 & 3,170 \\
\hline
\end{tabular}

a. Predictors: (Constant), disiplin kerja

b. Dependent Variable: kinerja karyawan

Dari tabel diatas, dapat dilihat bahwa nilai koefisien korelasi disiplin kerja terhadap kinerja karyawan adalah sebesar 0,459.

Nilai koefisien korelasi yaitu sebesar 0,459 hubungan terhadap kinerja karyawan memiliki hubungan yang sedang dan positif artinya. Artinya jika disiplin kerja meningkat maka kinerja karyawan menurun dan sebaliknya jika disiplin kerja menurun maka kinerja karyawan meningkat.

\section{f) Pengujian Hipotesis (Uji t)}

Uji t digunakan untuk mengetahui apakah masing-masing variabel bebasnya secara sendiri-sendiri berpengaruh secara signifikan terhadap variabel terikat. Uji $t$ menghasilkan satuan input sebagai berikut :

\section{Coefficients $^{\mathrm{a}}$}

\section{Tabel 9 \\ UJI t}

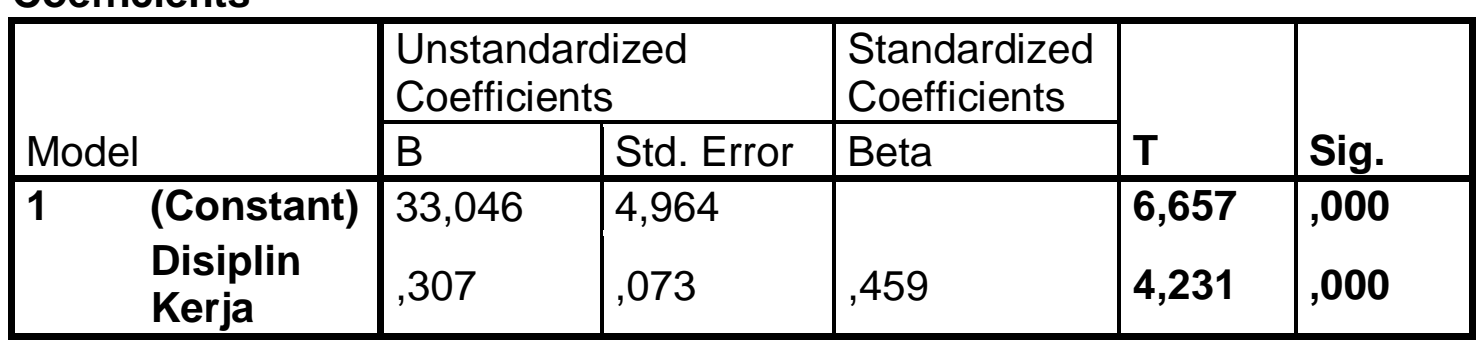

a. Dependent Variable: Kinerja Karyawan

Sumber : Data Diolah 2016

Uji t pada menunjukkan pengaruh kinerja dengan disiplin kerja dengan membandingkan nilai $t$ hitung dengan $t$ tabel, jika $t$ hitung $<t$ tabel maka disiplin kerja tidak berpengaruh pada kinerja karyawan.

Nilai $\mathrm{t}$ tabel $\mathrm{n}-2=69-2=67$ sampel dan alpha 0,05 adalah 1,996, sehingga uji $t$ sesuai tabel diatas adalah $: X=t$ hitung 4,231 sehingga lebih besar $t$ tabel 1,996, Ho ditolak dan $\mathrm{Ha}$ diterima dan berarti jika disiplin kerja meningkat maka kinerja karyawan menurun dan sebaliknya jika disiplin kerja menurun maka kinerja karyawan meningkat

\section{H. Pembahasan}

Dari hasil uji validitas output dapat diketahui nilai korelasi antara skor total item disiplin kerja, dan skor total item kinerja karyawan. Uji signifikansi dilakukan dengan membandingkan nilai $r_{\text {hitung }}$ dengan nilai $r_{\text {tabel. }}$ Jika $r_{\text {hitung }}>r_{\text {tabel }}$ dan berkorelasi positif, maka butir atau pertanyaan tersebut valid. Atau dengan kata lain item pertanyaan dikatakan valid apabila skor item pertanyaan memiliki korelasi yang positif dan 
signifikan dengan skor total variabel. Nilai ini dibandingkan dengan $r$ tabel dapat dicari pada signifikan 0,05 dengan uji dua sisi dan jumlah responden $n=69$. Maka didapat $r_{\text {tabel }}$ sebesar 0,444. Dengan demikian, dapat disimpulkan bahwa dari item pertanyaan variabel disiplin kerja dan kinerja karyawan dinyatakan valid semua karena $r$ hitung $>\quad r$ tabel.

Hasil uji reliabilitas dapat dilihat pada output reliabilitas statistik disiplin kerja dan kinerja karyawan. uji reliabilitas dilakukan terhadap item pertanyaan yang dinyatakan valid. Uji ini digunakan untuk mengukur suatu kuesioner yang merupakan indikator dari variabel atau konstruk. Suatu kuesioner dikatakan reliabel atau handal jika jawaban seseorang terhadap pernyataan adalah konsisten atau stabil dari waktu ke waktu. Suatu variabel dikatakan reliabel jika memiliki Cronbach Alpha> 0,60. Berdasarkan hasil yang diperoleh pada uji reliabilitas disiplin kerja dan kinerja karyawan diperoleh hasil Cronbach Alpha sebesar 0,906 dan 0,970, karena nilai Cronbach Alpha lebih besar dari 0,60 maka dapat disimpulkan bahwa seluruh item pertanyaan dari semua variabel dapat dinyatakan reliabel.

Hasil pengujian secara parsial (Uji t) dengan menggunakan uji 2 sisi dan tingkat signifikan $\alpha=5 \%$. Diperoleh thitung untuk disiplin kerja sebesar 4,231 dan $t_{\text {tabel }}$ sebesar 1,996. Artinya $t_{\text {hitung }}>$ $t_{\text {tabel }}=4,321>1,996$ maka Ho ditolak dan $\mathrm{Ha}$ diterima keputusan tersebut berarti terdapat pengaruh antara disiplin kerja terhadap kinerja karyawan.

\section{Kesimpulan dan Saran \\ 1. Kesimpulan}

Dari hasil analisis yang telah dilakukan serta hasil pembahasan maka dapat ditarik kesimpulan sebagai berikut :
1. Nilai koefesien korelasi $=0,459$ hal ini menunjukkan bahwa hubungan disiplin kerja terhadap kinerja karyawan pada PT. Agro Massiv International Group sedang dan positif.

2. Persamaan regresi linier sederhana yaitu $Y^{\prime}=33,046+$ $0,307 \quad X$ menunjukkan nilai konstan sebesar 33,046 artinya jika disiplin Kerja nilainya 0, maka kinerja karyawan nilainya 33,046. Sedangkan koefisien regresi variabel sebesar 0,307 artinya jika displin kerja sebesar 1 satuan maka kinerja karyawan akan mengalami peningkatan sebesar 0,307 dan sebaliknya apabila kinerja karyawan menurun sebesar 1 satuan maka disiplin kerja akan mengalami penurunan sebesar 33,046.

3. Hasil pengujian hipotesis dengan uji tdiperoleh kesimpulan terdapat pengaruh disiplin kerja terhadap kinerja karyawan.

\section{Saran}

Berdasarkan kesimpulan di atas yang telah diuraikan, maka penulis memberikan saran sebagai berikut :

1. Karyawan harus menyadari pentingnya disiplin kerja dalam melaksanakan tugas dan kewajiban yang dibebankan kepadanya sehingga karyawan hendaknya lebih bertanggungjawab lagi terhadap pekerjaan yang telah diberikan oleh perusahaan sehingga kinerja para karyawan dapat meningkat.

2. Perlunya diadakan penelitian lebih lanjut dengan menggunakan variabel yang berhubungan dengan disiplin kerja ataupun faktor-faktor lain yang mempunyai pengaruh terhadap kinerja karyawan. 
3. Untuk penelitian selanjutnya diharapkan untuk memperluas penelitian dengan cara membuat variabel penelitian yang berbeda

\section{DAFTAR PUSTAKA}

Hasibuan, S.P. Malayu. 2009. Manajemen Sumber Daya Manusia : Edisi Revisi Jakarta: Bumi Aksara.

Mangkunegara, A.A, Anwar. Prabu. 2014. Evaluasi Kinerja Sumber Daya Manusia. Bandung: Remaja Rosda Raya.

Priyatno, Duwi. 2014. SPSS 22 Pengolahan Data Terpraktis. Yogyakarta : Andi Offset.
Riduan. 2013. Dasar-Dasar Statistika, Edisi Revisi. CV. Bandung: Alfabeta.

Sugiyono. 2013. Statistik Untuk Penelitian, Alfabeta. Bandung 2015. Metode Penelitian Bisnis. Bandung: Alfabeta

2015. Prosedur penelitian kualitatif dan kuantitatif $R \& D$. Bandung: Alfabeta.

Sujarweni, 2014. Metode Penelitian. Yogyakarta: PUSTAKA BARU PRESS.

Wibowo. 2007. Manajemen Kinerja. PT. Raja Grafindo Persada 2016. Manajemen Kinerja : Edisi Keenam. Jakarta: Raja Grafindo Persada 